\title{
Challenges Associated with the Quantification of Tear Fluids
}

\section{Hardik Chandasana*}

Department of Pharmaceutics, College of Pharmacy, University of Florida, Gainesville, Florida, USA

\section{Editorial}

Eye is second most complex organ of the body after brain. Drug delivery to the eye is the challenging task for the pharmaceutical scientists. Topical administration to the eye is the most convenient and commonly used for the pharmacological therapy. Effectiveness of the drugs can only be determined by the pharmacokinetics and pharmacodynamics correlation. Ocular pharmacokinetics is the essential part in the drug development for the eye. Pharmacokinetics characteristics of the drug deliver to the eye is very complex. Moreover, assessment of the pharmacokinetic properties is very difficult. After topical administration of the drugs in to eye, collection of ocular tissue and aqueous humor is the routine practice in the animals. It's very difficult to conduct the study in humans. Thus, quantification of the tears is the most useful tools to study ocular pharmacokinetics [1-4].

Tear is constantly flawing from the basal glands at a flaw rate of $1.2 \mu \mathrm{L} / \mathrm{min}$. The total volume of tear in the human eye is $7-10 \mu \mathrm{L}$. Tear contains $0.6-0.8 \%$ protein in which albumin is around $0.4 \%$ [5]. Other ingredients in tear are such as sodium, potassium, urea, glucose, mucin etc. Tear flowrate can be higher under the physical or emotional stress [6]. The normal $\mathrm{pH}$ of tear fluids is 6.5 to 7.6 [7]. Most challenging and difficult part is the analysis of the tears. Analysis require sensitive methodology because the volume of the tear is very low $(2-3 \mu \mathrm{L})$. Tears can be collected by different methods such as Schirmer test strips, filter paper, cellulose sponges and graduated capillary. Unlike the other matrix such as plasma which can be collected easily and higher volume, but collection of tears also a challenging task. Schirmer test strips is the most widely used methodology for the tear collection because in this methodology tear can be collected in the large quantity also analysis is easier than other methodology as well as it causes less irritation [8-10]. Sampling method should be thoroughly standardized before beginning the pharmacokinetics.

Drugs can be extracted from the tears using simple protein precipitation, liquid-liquid extraction and solid phase extraction. Other issue associated with the method development is the availability of the blank tear matrix. To counter this issue artificial tear fluid can be prepared in the lab and method can be developed and validated and later selectivity can be assessed by using the actual tear. Complexity and availability of the tears makes interesting task for the pharmaceutical scientists to access the ocular pharmacokinetics [9-14].

\section{References}

1. Chandasana H, Prasad YD, Chhonker YS, Chaitanya TK, Mishra NN, et al. (2014) Corneal targeted nanoparticles for sustained natamycin delivery and their PK/PD indices: An approach to reduce dose and dosing frequency. Int $\mathrm{J}$ Pharm 477: 317-325.

2. Bhatta RS, Chandasana H, Rathi C, Kumar D, Chhonker YS, et al. (2011) Bioanalytical method development and validation of natamycin in rabbit tears and its application to ocular pharmacokinetic studies. J Pharm Biomed Anal 54: 1096-1100.

3. Chhonker YS, Prasad YD, Chandasana H, Vishvkarma A, Mitra K, et al. (2015) Amphotericin-B entrapped lecithin/chitosan nanoparticles for prolonged ocular application. Int J Biol Macromolec 72: 1451-1458.

4. Bhatta RS, Rathi C, Chandasana H, Kumar D, Chhonker YS, et al. (2011) LC-MS method for determination of amphotericin B in rabbit tears and its application to ocular pharmacokinetic study. Chromatographia 73: 487-493.
5. Mikkelson TJ, Chrai SS, Robinson JR (1973) Altered bioavailability of drugs in the eye due to drug-protein interaction. J Pharm Sci 62: 1648-1653.

6. Bright AM, Tighe BJ (1993) The composition and interfacial properties of tears tear substitutes and tear models. J Brit Contact Lens Ass 16: 57-66.

7. Abelson MB, Udell IJ, Weston JH (1981) Normal human tear $\mathrm{pH}$ by direct measurement. Arch Opth 99: 301-301.

8. Posa A, Bräuer L, Schicht M, Garreis F, Beileke S, et al. (2013) Schirmer strip vs. capillary tube method: non-invasive methods of obtaining proteins from tear fluid. Annals of Anatomy- Anatomischer Anzeiger 195: 137-142.

9. Arnold DR, Granvil CP, Ward KW, Proksch JW (2008) Quantitative determination of besifloxacin, a novel fluoroquinolone antimicrobial agent, in human tears by liquid chromatography-tandem mass spectrometry. J Chromatogr B 867: 105110.

10. Bhatta RS, Chandasana H, Chhonker YS, Rathi C, Kumar D, et al. (2012) Mucoadhesive nanoparticles for prolonged ocular delivery of natamycin: in vitro and pharmacokinetics studies. Int J Pharm 432: 105-112.

11. Byrro RMD, de Oliveira Fulgêncio G, da Silva Cunha A, César IC, Chellini PR et al. (2012) Determination of ofloxacin in tear by HPLC-ESI-MS/MS method: Comparison of ophthalmic drug release between a new mucoadhesive chitosan films and a conventional eye drop formulation in rabbit model. J Pharm Biomed Anal 70: 544-548.

12. Tian D, Feng F, Li Y, Yang J, Tian X, et al. (2008) Liquid chromatography-mass spectrometry method for the determination of thiamphenicol in rabbit tears. $J$ Pharm Biomed Anal 48: 1015-1019.

13. Hartmann A, Krebber R, Daube G, Hartmann K (2008) Pharmacokinetics of pradofloxacin and doxycycline in serum, saliva, and tear fluid of cats after oral administration. J Vet Pharmacol Ther 31: 87-94.

14. Grumetto L, Cennamo G, Del Prete A, La Rotonda MI, Barbato F (2002) Pharmacokinetics of cetirizine in tear fluid after a single oral dose. Clin Pharm 41: $525-531$

*Corresponding author: Hardik Chandasana, Department of Pharmaceutics, College of Pharmacy, University of Florida, Gainesville, FL 32610, USA, Tel: +1 352-213-9228; E-mail: hardik4587@gmail.com

Received October 20, 2016; Accepted October 21, 2016; Published November 11,2016

Citation: Chandasana H (2016) Challenges Associated with the Quantification of Tear Fluids. J Bioequiv Availab 8: e73. doi: 10.4172/jbb.10000e73

Copyright: $\odot 2016$ Chandasana H. This is an open-access article distributed under the terms of the Creative Commons Attribution License, which permits unrestricted use, distribution, and reproduction in any medium, provided the original author and source are credited. 